\title{
COVID-19: Beyond Respiratory Tract
}

\author{
Anshuman Elhence ${ }^{1} \quad$ Shalimar $^{1}$ \\ ${ }^{1}$ Department of Gastroenterology and Human Nutrition, \\ All India Institute of Medical Sciences, New Delhi, India
}

J Digest Endosc 2020;11:24-26

As we deal with the current pandemic of novel coronavirus disease 2019 (COVID-19), several studies have shed light on the hepatobiliary and pancreatic manifestations of the disease. What has emerged from the literature so far is that hepatobiliary involvement is relatively common, as evidenced by the large proportion of patients presenting with deranged liver enzymes. However, this seems to be clinically inconsequential in majority of patients. While it is postulated that the hit is likely to be more substantial in patients with preexisting severe liver disease and postliver transplant recipients, this is yet to be substantiated. The long-term consequences of COVID-19 infection and the drugs being used to combat it are currently unknown.

Severe acute respiratory syndrome-coronavirus-2 (SARS-CoV2) is responsible for COVID-19, closely resembles the other coronaviruses like SARS-CoV and Middle East respiratory syndrome coronavirus (MERS-CoV). A comparison between these three coronaviruses and their effect on the hepatic, pancreatic and biliary systems is shown in - Table $\mathbf{1}$.

We are learning in real-time every day about the clinical presentations, drug trials, and outcomes of COVID-19. In this issue, Singla and Arora extensively described the hepatobiliary and pancreatic manifestations of COVID-19. ${ }^{1}$ The clinical presentations described are predominantly from China, Italy, and the United States, and vary across the studies. The manifestations described are varied. The phenotypic presentations of viral illness are affected by multiple factors including the virus and the host. Due to the paucity of data, the hepatic, pancreatic, and biliary manifestations in Indians and their clinical relevance are yet unclear.

Existing literature suggests that liver enzyme elevation is higher in more severe cases requiring intensive care admission. In a retrospective analysis, it has been shown that a higher proportion of patients with abnormal liver function received lopinavir/ritonavir as compared with those with normal liver function. Also, patients with abnormal liver function had a more extended hospital stay as compared with those with normal liver function. ${ }^{2}$ Severe and acute
Address for correspondence Shalimar, Department of Gastroenterology and Human Nutrition, All India Institute of Medical Sciences, New Delhi 110023 India (e-mail: drshalimar@yahoo.com).

hepatitis has been reported rarely. Chen et al reported one patient with alanine aminotransferase (ALT) and aspartate aminotransferase (AST) levels of 7,590 and 1,445 U/L, respectively. ${ }^{3}$ Wander et al reported a COVID-19 patient with anicteric hepatitis with ALT and AST of 697 and 1,230 U/L, respectively. ${ }^{4}$

According to the data by a global registry of COVID-19 in patients with liver disease, so far in its fourth report, the mortality rate in 118 patients with cirrhosis (alcohol, $30 \%$; nonalcoholic fatty liver disease [NAFLD], 16\%; hepatitis B, $12 \%$; and hepatitis C, $10 \%$ ) was $40 \%$. In comparison, the mortality rate in 50 patients with chronic liver disease without cirrhosis was $12 \%$, and among 37 postliver transplant recipients was $22 \% .^{5}$ The causes of death and predictors of outcome in these patients with underlying cirrhosis are not clear, but this might be due to the cytokine storm stirred by the virus leading to multiorgan failures similar to acute-on-chronic liver failure (ACLF). Drug-induced liver injury (DILI) remains an important cause of liver injury in these patients. With no currently approved therapy, several new drugs are being tested, which have well-known hepatotoxicities, concerns of exacerbating liver diseases, and interactions with other drugs given to patients with liver disease (-Table 2). It is also not clear if changing immunosuppression among autoimmune hepatitis and postliver transplant patients may alter the risk and outcomes of COVID-19.

Elevated amylase has been reported in COVID-19; its significance is unclear. Liu et al in a series of 121 COVID-19 patients reported pancreatic injury in the form of increased lipase in 11 (16\%), and imaging alterations in the form of focal head enlargement and duct dilatation in $5(7.4 \%)$ out of 67 patients with severe COVID-19 disease; however, pancreatic necrosis was not seen in any patient. ${ }^{6}$

Importantly, as we gain more insight about the hepatobiliary manifestations of COVID-19, the hepatologists, gastroenterologists, and gastrointestinal (GI) surgeons must not take a backseat. We should remain aware that patients with cirrhosis and COVID-19 have high mortality, close to $40 \%,{ }^{5}$ similar to patients with ACLF. ${ }^{7}$ We must also keep a keen eye 
Table 1 Comparison of the coronaviruses

\begin{tabular}{|c|c|c|c|}
\hline & SARS-CoV & MERS-CoV & SARS-CoV2 \\
\hline Disease & SARS & MERS & COVID-19 \\
\hline Year of spread & $2002-2003$ & 2012 & $2019-2020$ \\
\hline Homology to SARS-CoV2 genome (\%) & 82 & 50 & 100 \\
\hline Intermediate host & Palm civets & Dromedary camels & Pangolins \\
\hline Route of transmission & Droplet, contact & Contact & Droplet, contact \\
\hline Receptor for virus & ACE-2 & DPP-4 & ACE-2 \\
\hline Mortality (approximate \%) & 10 & 33 & $2-10$ \\
\hline $\begin{array}{l}\text { Evidence of liver injury-elevated } \\
\text { enzymes (\%) }\end{array}$ & 60 & 30 & $14-53$ \\
\hline Direct hepatotoxicity/inclusions & Present & Absent & Unknown \\
\hline $\begin{array}{l}\text { Demonstration of viral nucleic acid in } \\
\text { hepatocytes }\end{array}$ & + & - & - \\
\hline Drugs implicated in hepatotoxicity & $\begin{array}{l}\text { Ribavirin, macrolides, } \\
\text { steroids }\end{array}$ & - & $\begin{array}{l}\text { Lopinavir/ritonavir, steroids, mac- } \\
\text { rolides, remdesivir, tocilizumab }\end{array}$ \\
\hline Worse outcomes in viral hepatitis & + & - & Unknown \\
\hline Biliary system & + & - & + \\
\hline Pancreas & + & - & + \\
\hline
\end{tabular}

Abbreviations: ACE2, angiotensin converting enzyme-2; CoV, coronavirus; COVID-19, novel coronavirus disease 2019; DPP4, dipeptidyl peptidase 4; MERS, Middle Eastern respiratory syndrome; SARS, severe acute respiratory syndrome.

Table 2 Important drugs under trial for COVID-19 and their effect on liver

\begin{tabular}{|c|c|c|c|}
\hline $\begin{array}{l}\text { Serial } \\
\text { no. }\end{array}$ & Drug & Mechanism of Action & Comments About Liver Safety \\
\hline 1 & $\begin{array}{l}\text { Hydroxychloroquine (HCQ) and } \\
\text { chloroquine (CQ) }\end{array}$ & $\begin{array}{l}\text { Inhibition of viral entry via ACE-2 } \\
\text { and interference with endosomal } \\
\text { acidification }\end{array}$ & $\begin{array}{l}\text { Hepatotoxicity is rare with HCQ } \\
\text { Possible drug interactions with immunosup- } \\
\text { pressive drugs }\end{array}$ \\
\hline 2 & Azithromycin & $\begin{array}{l}\text { Immunomodulatory action to inhibit } \\
\text { virus }\end{array}$ & $\begin{array}{l}\text { Significant drug interactions } \\
\text { Self-limiting cholestatic hepatitis }\end{array}$ \\
\hline 3 & Lopinavir/ritonavir & $\begin{array}{l}\text { Inhibits coronavirus replication by } \\
\text { binding to Mpro, a protein critical to its } \\
\text { replication. }\end{array}$ & $\begin{array}{l}\text { Elevation in liver enzymes. } \\
\text { Significant drug interaction with calcineurin } \\
\text { and mTOR inhibitors }\end{array}$ \\
\hline 4 & Remdesivir & $\begin{array}{l}\text { Adenosine analog which inhibits RNA } \\
\text { dependent RNA polymerase }\end{array}$ & $\begin{array}{l}\text { Sparse data available, however concern for } \\
\text { hepatotoxicity exist }\end{array}$ \\
\hline 5 & Favipiravir & $\begin{array}{l}\text { RNA dependent RNA polymerase } \\
\text { inhibitor }\end{array}$ & Risk of hepatitis \\
\hline 6 & Tocilizumab/sarilumab/siltuximab & $\begin{array}{l}\text { Monoclonal antibody against IL- } 6 \\
\text { receptor }\end{array}$ & $\begin{array}{l}\text { Risk of hepatotoxicity and exacerbation of } \\
\text { viral hepatitis }\end{array}$ \\
\hline 7 & IFN- $\alpha$ & Immunomodulator & $\begin{array}{l}\text { Contraindicated in patients with decompen- } \\
\text { sated liver disease }\end{array}$ \\
\hline 8 & Ribavirin & $\begin{array}{l}\text { Guanosine analog which inhibits inosine } \\
\text { monophosphate dehydrogenase }\end{array}$ & $\begin{array}{l}\text { May exacerbate hemolysis and lead to jaun- } \\
\text { dice by causing indirect hyperbilirubinemia }\end{array}$ \\
\hline 9 & Anakinra & Recombinant IL-1 receptor antagonist & $\begin{array}{l}\text { No risk of hepatotoxicity or exacerbation of } \\
\text { viral hepatitis }\end{array}$ \\
\hline 10 & Convalescent plasma & Antibodies directed against SARS-Cov2 & $\begin{array}{l}\text { Risk of transmission of viral hepatitis via } \\
\text { plasma }\end{array}$ \\
\hline 11 & Baricitinib & $\begin{array}{l}\text { Janus kinase inhibitor inhibits cytokine } \\
\text { signaling via the JAK-STAT pathway }\end{array}$ & High risk of reactivation of viral hepatitis \\
\hline
\end{tabular}

Abbreviations: ACE-2, angiotensin-converting enzyme-2; CoV, coronavirus; COVID-19, novel coronavirus disease 2019; IFN, interferon; IL, interleukin; JAK, janus kinase; mTOR, mammalian target of rapamycin; SARS, severe acute respiratory syndrome; STAT, signal transducer and activator of transcription. 
on the hepatosafety of the new drugs under development for COVID-19.

India is a young country with a high prevalence of diabetes, hypertension, and coronary artery disease. These comorbidities have been reported to be associated with poor outcomes in COVID-19. As per a study by Mukherjee et al, the burden of chronic liver disease in India is high, and it accounts for $1.28 \%$ of patients presenting to hospital, and hence at risk of nosocomial transmission. ${ }^{8}$ NAFLD prevalence in India is as high as 9 to $30 \%$. These patients might be at risk of adverse outcomes from COVID-19 because of associated risk factors for severe disease such as diabetes, hypertension, and cardiac comorbidity. Indian Council of Medical Research (ICMR) has a national registry of COVID-19 which will help in understanding the manifestations of COVID-19 in India. The effect of COVID-19 on the underlying liver disease and vice versa remains unanswered at present. Several new drugs and experimental therapies are being tried. We hope that these issues can be better understood as more information pours in, and we are better prepared for the future.

\section{References}

1 Singla V and Arora A. Hepatobiliary and Pancreatic Manifestations of Coronavirus Disease 2019. J Digest Endosc 2020;11:21-23

2 Fan Z, Chen L, Li J, et al. Clinical features of COVID-19related liver damage. Clin Gastroenterol Hepatol 2020;0(0):S1542-3565(20)30482-1

3 Chen N, Zhou M, Dong X, et al. Epidemiological and clinical characteristics of 99 cases of 2019 novel coronavirus pneumonia in Wuhan, China: a descriptive study. Lancet 2020;395(10223):507-513

4 Wander P, Epstein M, Bernstein D. COVID-19 presenting as acute hepatitis. Am J Gastroenterol 2020

5 COVID-Hep registry. Available at: https://www.covid-hep.net/ updates.html. Accessed April 22, 2020

6 Liu F, Long X, Zhang B, Zhang W, Chen X, Zhang Z. ACE2 expression in pancreas may cause pancreatic damage after SARS-CoV-2 infection. Clin Gastroenterol Hepatol 2020;(e-pub ahead of print). doi:10.1016/j.cgh.2020.04.040

7 Shalimar, Kumar D, Vadiraja PK, et al. Acute on chronic liver failure because of acute hepatic insults: Etiologies, course, extrahepatic organ failure and predictors of mortality. J Gastroenterol Hepatol 2016;31(4):856-864

8 Mukherjee PS, Vishnubhatla S, Amarapurkar DN, et al. Etiology and mode of presentation of chronic liver diseases in India: a multi centric study. PLoS One 2017;12(10):e0187033 